\title{
İstanbul Sağmalcılar Kolera Salgını (1970)
}

\section{Cholera Outbreak in İstanbul, Sağmalcılar (1970)}

\author{
Barış ERTEM $^{\mathrm{a} *}$
}

a Öğr.Gör.Dr., İstanbul Teknik Üniversitesi, Atatürk İlkeleri ve İnkılâp Tarihi Bölümü, İstanbul / TÜRKIYYE ORCID: 0000-0001-5091-2807

\section{A K A L E B İ L G İ S İ \\ Makale Geçmişi: \\ Başvuru tarihi: 1 Temmuz 2020 \\ Kabul tarihi: 23 Ekim 2020}

\section{Anahtar Kelimeler:}

Kolera,

Kolera salgını,

Türkiye,

İstanbul,

Sağmalcılar

\section{ARTICLE INFO}

Article History:

Received July 1, 2020

Accepted October 23, 2020

\section{Keywords:}

Cholera,

cholera outbreak,

Turkey,

İstanbul,

Sağmalcılar

\begin{abstract}
Ö Z
1961 yılında Filipinlerde başlayan "El Tor” tipi kolera salgını, 1965 yılı itibariyle Rusya ve İran'da etkili olmaya başlayarak sınırlarımıza kadar dayanmıştır. Salgının komşu ülkelerde görülmesi üzerine, Türkiye'de zaten başlatılmış olan tedbirler sıkılaştırılmış, sınırlara kontrol birimleri ve laboratuvarlar kurulmuş, gümrükler, hava ve deniz limanlarında yoğun denetimler başlamış, ilaç, serum ve tıbbî malzeme stoklanmış, yoğun bir aşı uygulaması bașlatılmıștır. Resmî sayılara göre, salgın ülkemize ulaşana kadar ülke çapında yaklaşık on milyon, ülkemize ulaşmasından sonra da yaklaşık on beş milyon kişiye kolera aşısı uygulanmıştır. Bazı hastaneler "kolera hastanesi" olarak ayrılmış, salgının görüldüğ̈̈ İstanbul'un kritik ilçe ve semtlerine sağlık ekipleri sevk edilmiştir. Klorlama ve dezenfeksiyon çalışmaları hızlandırılmış, bazı kanalizasyon sistemleri ve kaçak kuyular kapatılmış, şehir suları gözden geçirilmiş, okullarda da yoğun bir aşı kampanyası başlatılıı̧ ve aşı uygulamasına toplumdan yoğun katılım sağlanmıştır. Ayrıca, tavsiye edilen tedbirlere de büyük ölçüde uyulmuştur. Alınan tedbirler sayesinde, salgın, yaklaşık iki hafta içerisinde, patlak verdiği İstanbul sınırlarını aşmadan kontrol altına alınmış ve resmî açıklamalara göre 3 Kasım 1970 günü itibariyle sona ermiştir. Bu süre içerisinde bin beş yüz kadar hastanın iyileşmesi sağlanmıș, Sağlık ve Sosyal Yardım Bakanlığı verilerine göre elli iki vatandaşımız da kolera salgını sebebiyle hayatını kaybetmiştir.
\end{abstract}

\section{A B S T R A C T}

The "El Tor" type cholera epidemic, which started in the Philippines in 1961, started to be effective in Russia and Iran as of 1965 and reached borders of Turkey. Upon the outbreak seen in neighboring countries, measures have been tightened in Turkey, border checkpoints and laboratories are established. Intense controls have started in airports and seaports, pharmaceutical, serum and medical equipment have been stocked and an intensive vaccination has been initiated. Some hospitals were assigned as "cholera hospital". Health teams were dispatched to the critical districts of Istanbul, where the epidemic was observed. Chlorination and disinfection processes were accelerated. Some sewage systems and illegal wells were closed. The mains water was examined. An intensive vaccination campaign has been launched in schools. According to official statements, ten million people were vaccinated against cholera two months before the outbreak. During the outbreak, fifteen million people were vaccinated against cholera. Vaccination was free. Citizens were generally interested in vaccination. The recommended measures were generally followed. As a result of the measures taken, the outbreak was brought under control within two weeks without exceeding the borders of Istanbul. According to official statements, it ended on November 3, 1970. About one thousand and five hundred patients recovered during the outbreak. According to ministry data, fifty-two people died due to cholera.

\footnotetext{
* Sorumlu yazar/Corresponding author.

e-posta: ertbar@gmail.com
} 


\section{EXTENDED ABSTRACT}

According to official records, a cholera outbreak began in İstanbul, Turkey on October 13, 1970. Authorities described this outbreak "El Tor" Type. It was reported as "Para-Cholera in the press. Authorities also said that this epidemic was not as deadly as the "Asian Cholera". The place, where the epidemic started,was Sağmalc1lar, a poor district of İstanbul. It was an old and poor district with lacking hygiene requirements. Also, there were many old sewers and illegal wells in the region.

The cholera outbreak, that started in 1970 in Istanbul, was part of the cholera pandemic that started in Asia in 1961. There, in January 1961, a major Cholera epidemic began in the seaport of Makassar. In the years of 1961 and 1962, most of the island territories in Southeast Asia were infected. It is estimated that over twelve thousand cases and nearly two thousand human deaths occurred in these areas during 1961. In 1962, there were over thirteen thousand cases and almost two thousand deaths more. In 1963, El Tor invaded the Asian mainland and reinfected all the Western Pacific rim countries except Taiwan. Malaysia was attacked in May, Korea in September and Bangladesh in December. Also by December, Singapore, Thailand, Cambodia and Burma (Myanmar) were infected. Vietnam was stuck in January 1964. The epidemic penetrated India in March 1964. In less than a year, most of the country was engulfed (Kohn, 2008, s.20).

From India, the disease traveled to Pakistan in June 1965 and very quickly to Afghanistan. Iran (July, 1965) and adjoining territories of the former Soviet Union (August, 1965) (Kohn, 2008, s.20).

The year of 1970 was one of the worst in the history of cholera. The pandemic intensified once again to infect twentyfour countries in the world. Russian authorities announced an imported outbreak caused by the Vibrio El Tor in the city of Astrakhan on August, 1970. Subsequently, between August and September 1970, El Tor outbreaks reported from six Middle East countries. Lebanon, Israel, Dubai, Syria, Jordan and Saudi Arabia. Also hit were Libya, Odessa (Ukraine) and Tunisia. İstanbul (Turkey) experienced a virulent attack in October as did Czechoslovakia (Kohn, 2008, s.20).

Upon the outbreak seen in neighboring countries, measures have been tightened in Turkey, border checkpoints and laboratories are established. Intense controls have started in airports and seaports, pharmaceutical, serum and medical equipment have been stocked and an intensive vaccination has been initiated.

Despite intensive measures taken, cholera was seen in Turkey in October 13, 1970. The place, where the epidemic started, was Sağmalcılar, a poor district of İstanbul. Thoroughly measures were increased after the outbreak detected in Turkey. Vacant beds in hospitals and prisons in İstanbul reserved for cholera patients. Some hospitals were assigned as "cholera hospital". Health teams were dispatched to the critical districts of Istanbul, where the epidemic was observed. Chlorination and disinfection processes were accelerated. Some sewage systems and illegal wells were closed. The mains water was examined. Sale of iced products, such as ice cream, is forbidden. Sale of all types of juices banned in schools. The people, who living in the houses with the disease, were asked not to go out for five days. These houses were disinfected. Vehicles, that carrying cholera patients were disinfected every day. These vehicles were not used for any other purpose. An intensive vaccination campaign has been launched in schools. According to official statements, ten million people were vaccinated against cholera, two months before the outbreak. During the outbreak, fifteen million people were vaccinated against cholera. Vaccination was free. Citizens were generally interested in vaccination. The recommended measures were generally followed.

Governor of İstanbul, Vefa Poyraz announced on October 20, 1970, that the epidemic weakened by thirty-three percent. Poyraz made a new statement on October 21, 1970, reporting that the outbreak was weakened by sixty percent. There was no death due to cholera on October 22, 1970 in Turkey. Minister of Health, Dr. Vedat Ali Özkan announced on October 28, 1970 that the epidemic weakened by ninety percent. Also, no deaths were due to cholera during the whole week.

Minister of Health, Dr. Özkan announced on November 3, 1970, that the cholera outbreak was completely under control. No deaths were due to Cholera since October 26, 1970. Also, fifteen million people were vaccinated in the entire Turkey.

As result of the measures taken, the outbreak was brought under control within two weeks without exceeding the borders of Istanbul. According to official statements, it ended on November 3, 1970. About one thousand and five hundred patients recovered during the outbreak. According to ministry data, fifty-two people died due to cholera. 


\section{Giriş}

Tarih boyunca salgın hastalıklar toplumları sosyal, ekonomik ve siyasî açıdan olumsuz etkilemiştir (Özlü ve Çay, 2020, s.17). Özellikle XVII.yüzyıldan itibaren dünya genelinde ortaya çıkan veba ve kolera gibi salgınlar sebebiyle Anadolu'da binlerce insan yaşamını yitirmiştir (Çalışkan, 2019, s.1556). XVIII.yüzyıldan itibaren de İstanbul veba, kolera ve cüzam gibi salgınlar ile tanışmış ve salgınlar XX.yüzyılda da devam etmiştir (Yıldırım, 2010, s.5860,73). Bu nedenle toplumlar, salgınlara karşı mücadele etmek için büyük çaba göstermişlerdir (Özlü ve Çay, 2020, s.17). Özellikle XIX.yüzyılda karantina uygulaması ${ }^{1}$ salgın görülen her yerde uygulanmış ve bu yüzyılda karantinanın yaygın hale getirilmesi ile yeni sağlık yöntemleri diğer ülkelerde olduğu gibi Anadolu ve Doğu Akdeniz'de salgınların büyük oranda azalmasını sağlamıştır (Çalışkan, 2020, s.8).

Ancak, 1961 yılında Filipinler'de ortaya çıkan ve 1965 yılında İran ve Rusya'da etkili olmaya başlayıp Avrupa'ya kadar sıçrayan "El Tor" tipi bir salgının uzantısı olan kolera salgını, 1970 yılının sonlarında İstanbul'un Sağmalcılar semtinde tekrar ortaya çıkmıştır (Millet Meclisi Tutanak Dergisi, s.641). Bazı yabancı kaynaklar ise salgının başlangıç noktasının Endonezya'nın Makassar liman bölgesi olduğu bilgisini vermektedir. Bu merkezden başlayan salgın, 1962 yılına kadar tüm Güneydoğu Asya adalarını etkisi altına almıştır. 1961 yılı sonları itibariyle salgının görüldüğ̈ bölgelerde on iki binden fazla hasta ve iki binden fazla ölüm olayı raporlanmıştır. 1962 yılında bu sayıya on üç bin hasta ve yaklaşık iki bin yeni ölüm daha eklenmiştir. 1963 yılında da Pasifik adalarından Asya kıtası ülkelerine ulaşan salgın, Tayvan dışında tüm Batı Pasifik hattı ülkelerini etkisi altına almıştır. 1964 yılının Mart ayında Hindistan'a ulaşan salgın, yaklaşık altı ay içerisinde tüm Hindistan'da görülmüştür. 1965 yılında Hindistan üzerinden Pakistan ve Afganistan'a ulaşan salgın, aynı yıl İran ve Sovyetler Birliği topraklarında da ortaya çıkmış ve sınırlarımıza kadar dayanmıştır (Kohn, 2008, s.20).

Hastalık, İran'da koleradan gerçekleşen ilk ölümlerin fark edilememesi sebebiyle kısa sürede tüm ülkeyi etkisi altına alan bir salgın haline gelmiştir. Afganistan'dan İran'a geçen iki kaçakçının bu hastalıktan ölmüş olmaları ve bu kişilerin doktorlar tarafından otopsiye gerek duyulmadan ve tedbir alınmadan defnedilmeleri, daha sonraki birkaç ay boyunca ishal vb sebeplerle artan ölümlerin de dikkate alınmaması sonucu ülkede patlak veren salgın, resmî kayitlara göre iki binden fazla kişinin ölümüne neden olmuştur. Adalet Partisi Eskişehir Milletvekili Dr. Mehmet Şemsettin Sönmez'in Meclis'te konuyla ilgili verdiği bilgiye göre, yabancı hükümetler ölü sayılarını doğru olarak açıklamadıklarından, salgının boyutu ve ölüm sayısı görünenden çok daha büyüktür. Yine aynı konuşmasında Sönmez, İranlı bir meslektaşının, kendisine bu salgını kontrol altına alabilmek için 400 milyon dolar harcamak zorunda kaldıkları bilgisini vermiştir. Bu durum, sınırımızdaki salgının resmî açıklamalar dışındaki gerçek boyutu hakkında fikir vermektedir (Millet Meclisi Tutanak Dergisi, s.639).

\footnotetext{
${ }^{1}$ Türkiye'de karantina uygulaması hakkında geniş bilgi için: Bedi N. Şehsuvaroğlu, Türkiye Karantina Tarihine Giriş, (İstanbul Üniversitesi Tıp Fakültesi Mecmuası, No:1, Sene: 1958'den ayrı baskl), İstanbul: 1958
} 


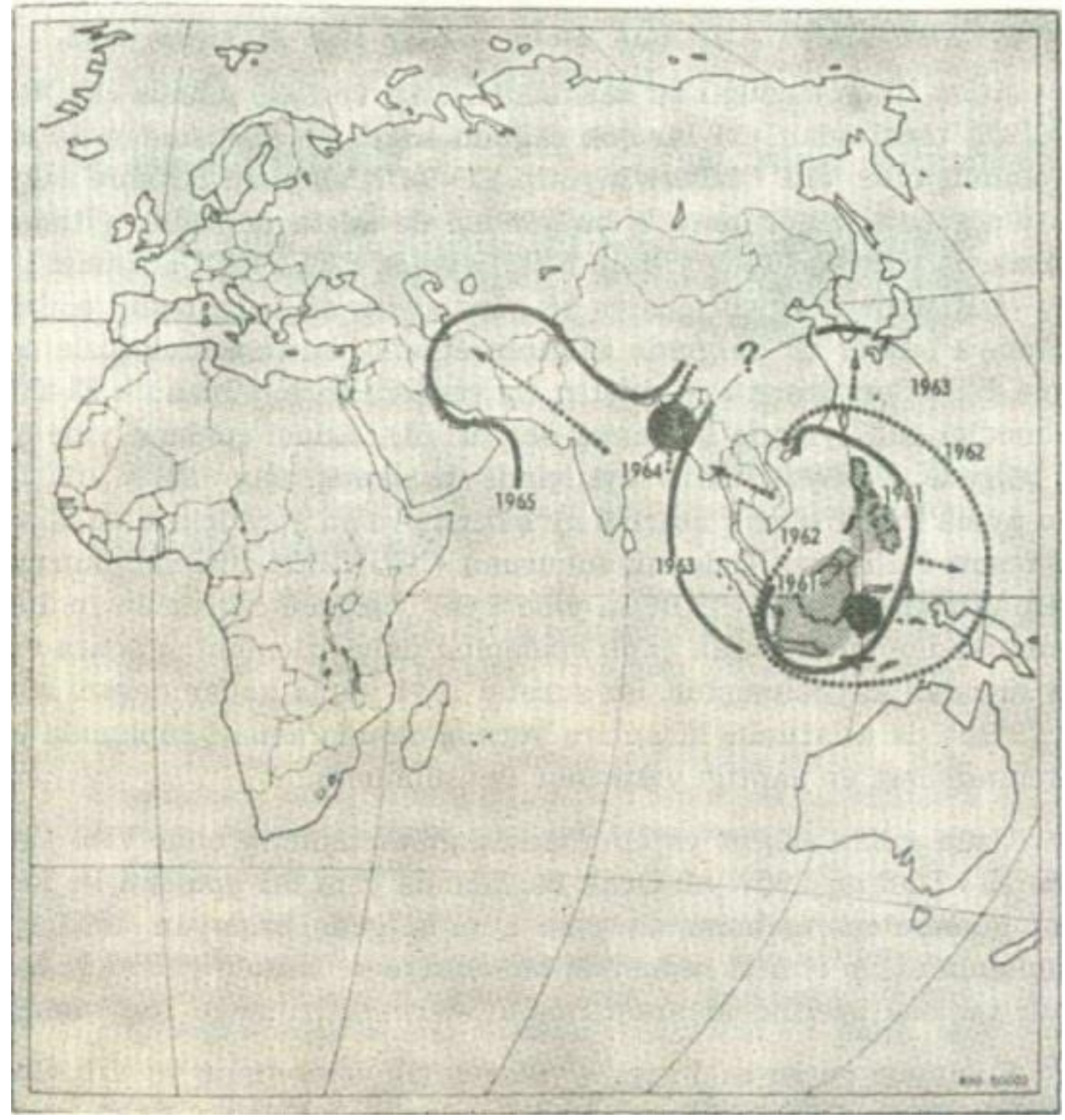

Şekil 1: Kolera salgınının küresel durumu (1961-1965) Kaynak: Gürer ve Meriç, 1971, s.112

Nitekim, İran'da kontrol altına alınamayan salgın, aynı dönemde Sovyetler Birliği’ne sıçramıştır. Dönemin Sağlık ve Sosyal Yardım Bakanı Dr. Vedat Ali Özkan'ın Millet Meclisi'ndeki bir konuşmasında verdiği bilgilere göre, hastalık Sovyetler Birliği topraklarında ilk olarak Astragan bölgesinde görülmüştür. Bu bölge sıkı bir karantina altına alınmış olmasına karşın, hastalık kısa sürede Odessa (Kırım)'ya sıçramış ve bu bölge de tecrit altına alınmıştır. Ancak, Sovyet Hükümeti'nin sıkı tedbirlerine karşın Kerç (İyekaterinoslav-Ekaterinoslav)'e kadar sıçrayan salgın, daha sonra Çekoslovakya üzerinden Avrupa'yı etkisi altına almaya başlamıştır. Yine Özkan'ın verdiği bilgiye göre, salgın, sınırımızdaki diğer bir ülke olan Suriye'de de etkisini sürdürmektedir. Suriye Hükümeti resmî bir açıklama yapmamasına karşın, 1971 yılının Ocak ayı itibariyle Hama ve Humus² ${ }^{2}$ bölgeleri karantina altındadır (Millet Meclisi Tutanak Dergisi, s.657).

Salgının Türkiye'de ortaya çıkması ise yakın coğrafyası ve komşularından beş yıl kadar sonra, 1970 yılının Ekim ayında olmuştur. Kamuoyu, salgının varlığını 17 Ekim 1970 tarihinde

\footnotetext{
${ }^{2}$ XIX.yüzyılda bölgede kolera salgınından ölenler hakkında geniş bilgi için: Adem Çalışkan ve Ahmet Eyicil, "XVIII. ve XIX.Yüzyılda Halep ve Civarında Salgın Hastalıklar”, Bingöl Üniversitesi Sosyal Bilimler Enstitüsü Dergisi, Cilt 9, Sayı: 18, Güz 2019, s.1289-1319
} 
haberlerin basında yer almasıyla birlikte öğrenmiştir (Akşam, 17 Ekim 1970; Milliyet, 17 Ekim 1970). Hastane kayıtlarına göreyse salgın, aslında 4 gün kadar önce, 12-13 Ekim 1970 tarihinde tespit edilmiştir.

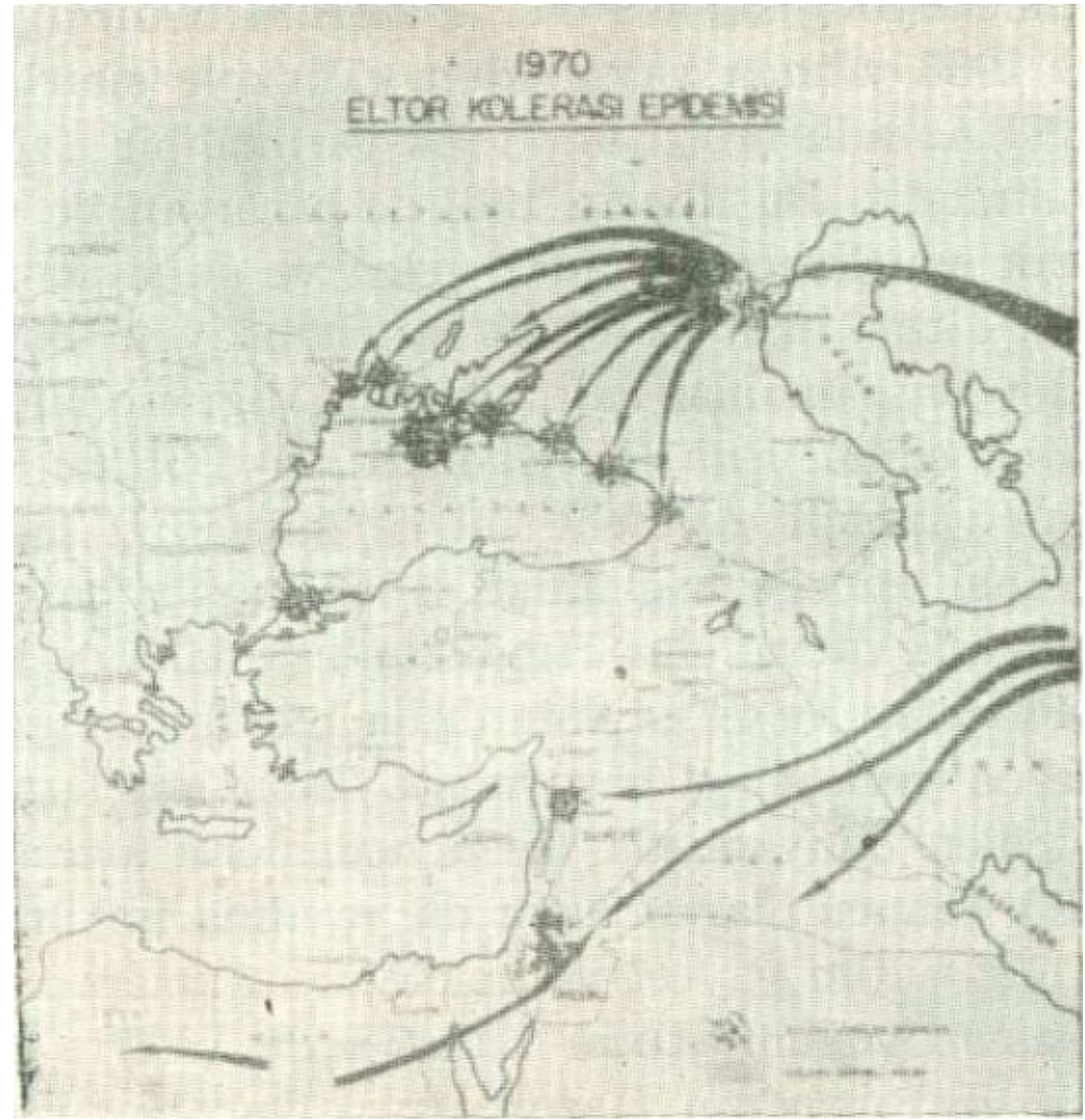

Şekil 2: Küresel kolera salgınının Sovyetler Birliği, İran ve Suriye üzerinden sınırlarımıza ulaşması ve bizde görüldüğü bölge. Kaynak: Gürer ve Meriç, 1971, s.114

İstanbul'da yaşanan bu kolera salgını hakkında yayımlanmış çok az sayıdaki bilimsel çalışmadan biri olan, salgında da görev yapmış GATA hekimleri Dr. İsmail Gürer ve Doç. Dr. Nihat Meriç'in hazırlamış olduğu "2200 Kişilik Toplumda Kolera Portörlüğü Araştırması ” adlı makaleye göre, Türkiye'ye ulaşan salgın, yukarıda da ifade edildiği gibi 1961 yılında başlayıp sınırımıza kadar gelen “El Tor'dan olma” yeni bir kolera saldırısı dönemidir. Salgın, 1965 yılında İran'a, buradan da sınırlarımıza ulaştıktan sonra Türkiye'de yoğun tedbirler alınmış, bir "savunma duvarı" örülmüştür (Gürer ve Meriç, 1971, s.114).

Salgın Türkiye sınırlarına yaklaştıkça basının da ilgisini çekmiş ve yakından takip edilerek haber yapılmaya başlamıştır. Örneğin, 18 Ağustos 1970 tarihinde yayımlanan bir habere göre, kolera salgını Rusya'dan sonra Suriye'de de ortaya çıkmıştır. Hastalığın görüldüğü yer ise sınırımıza yalnızca $90 \mathrm{~km}$ kadar uzaklıktaki Hama şehridir. Salgının Türkiye’ye ulaşmaması için sınır boyunca karantina merkezleri kurulmuștur. Ayrıca, nüfusu sebebiyle salgın açısından en riskli bölge olarak kabul edilen İstanbul'da da şebeke suyu dezenfekte 
edilmiştir. Havalimanlarında da karantina önlemlerinin başladığı bugünlerde, dönemin Sağlık ve Sosyal Yardım Bakanı Dr. Vedat Ali Özkan'ın kaygısı, salgının Suriye'den Türkiye'ye geçen kaçakçılar aracılığıyla Türkiye'ye ulaşmasıdır. Bu olasılığa karşı alınması gereken tedbirler de basında yer almaya başlamış ve bu tedbirler şu şekilde sıralanmıştır (Milliyet, 18 Ağustos 1970):

- Şehir suyu devamlı klorlanmalıdır.

- Kaynağı belli olmayan su kullanılmamalıdır.

- Yiyecekler mutlaka temiz su ile yıkanmalıdır.

- Özellikle ishal şikâyeti olan hastalar hemen doktora başvurmalıdır.

- Tüm vatandaşları kapsayan bir aşı kampanyası başlatılmalıdır.

- Şehirlerdeki açık kanalizasyonlar kapatılmalı ve sinekle sürekli mücadele edilmelidir.

Yukarıdaki haber ve uyarılardan hemen bir gün sonra, 19 Ağustos 1970 tarihli Dünya Gazetesi'nin haberine göre, Türkiye'de koleraya karşı aşı kampanyası başlatılmıştır. O güne kadar yalnızca isteyen vatandaşlara aşı uygulanırken, bundan sonra Ankara' dan başlanarak tüm vatandaşlar aşılanacaktır. Hıfzıssıhha Enstitüsü'nde kolera aşısı uygulaması yapan servisleri kontrol eden Bakan Özkan, Çubuk Devlet Hastanesi'nin bir süre için "karantina hastanesi" hâline getirildiğini, hastanenin yatak, hekim ve yardımcı sağlık personeli sayısının artırıldığını söylemiştir. Bununla birlikte, hastanede bulunan hastalardan da durumu uygun olanlar taburcu edilmeye ya da başka hastanelere sevk edilmeye başlamıştır (Dünya, 19 Ağustos 1970).

Ayrıca, salgının sınırlarımıza dayandığı bu tarihlerde başta sınır bölgeleri olmak üzere, gerekli görülen bölgelerde “antero bakteri üniteleri” kurulmuş ${ }^{3}$ ve olası bir salgının erken tespiti için çalışılmıştır. Bu birimler, elde ettikleri verileri düzenli olarak üst laboratuvar ve hıfzıssıhha enstitülerine göndermiştir. Çalıştıkları dönem boyunca da bu birimlerde yüz binlerce tahlil ve analiz yapılmıştır. Ayrıca serum ile ilaç stoklaması ve kolera hastaları için özel tasarlanmış yatakların temini de başlatılmıştır. 1966 yılında ise şehir sularının dezenfeksiyonu hakkında bir yönetmelik yayımlanmış ve bütün ülkeye klorlama için malzeme dağıtılmıştır. Salgının Rusya'ya ulaşıp iyice büyümesiyle birlikte, 1970 yılının Temmuz ayında tüm sınırlar, Karadeniz Bölgesi, Marmara Bölgesi, İstanbul, Adana ve Hatay "hassas bölge" ilân edilerek bu bölgelerde salgının Türkiye'de görüldüğü Ekim ayına kadar toplam on milyon kişiye aşı uygulanmıştır. Bunun bir milyonu İstanbul'da yaşayan insanlara yapılmıştır. Sınır kapıları, hava ve deniz limanlarında da tedbirler alınarak kontroller başlatılmıştır (Millet Meclisi Tutanak Dergisi, s.649-652). Nitekim, Türkiye'nin tedbirlerini artırdığı bu beş y1l içerisinde salgın Irak, Suriye, Kırım, Rusya ve İsrail’i etkisi altına alarak Akdeniz, Karadeniz ve Ortadoğu sınırlarımızı kuşatmıştır.

\section{Salgının Türkiye'ye Ulaşması ve Gelişimi}

Türkiye'nin almış olduğu tüm tedbirlere ve salgının sınırlarından girmesini beş yıl kadar geciktirmeyi başarmış olmasına karşın, 1970 yılının sonlarında salgın Türkiye'ye de ulaşmıştır. Kayıtlara göre hastalığın ilk görüldüğü yer, çevre sağlığı şartlarını sağlayamamış, hijyen ve ekonomi açılarından zayıf, yoksul ve kozmopolit bir İstanbul semti olan Sağmalcılar'dır (Gürer ve Meriç, 1971, s.113-114). Salgının kaynağı Türkiye dışındandır. Patlak vermesinin sebebiyse, semtin içme ve kullanma suyuna kanalizasyon suyunun karışması olmuştur. İlçenin pek çok yerinde halen Bizans döneminden kalma sarnıçlar ve kontrolsüz olarak açılmış, hijyen şartlarından yoksun kuyular kullanılmaktadır.

13 Ekim Salı günü aynı saatlerde İstanbul Üniversitesi Cerrahpaşa Hastanesi'ne on, Çapa Kliniği'ne on beş ve Samatya Devlet Hastanesi'ne sekiz kişi başvurmuştur. Hastaların

\footnotetext{
${ }^{3}$ Konuyla ilgili kaynaklar ve resmî açıklamalarda "antero bakteri ünitesi” olarak adlandırılan tesisler, hastalık hakkında test yöntemiyle yüksek sayıda veri toplayarak teşhis için merkez laboratuvarlara gönderen küçük test merkezleridir.
} 
hastaneye başvurma saatleri gibi şikâyetleri de benzerdir. Hepsinde ishal ve kusma gibi belirtiler söz konusudur. Hastalara hemen müdahale edilmiş ve olumlu sonuç alınmıştır (Bakar, 2017, s.248). Tespit edilen ve yaklaşık iki hafta kadar etkili olan salgın, Sağlık ve Sosyal Yardım Bakanı'nın Meclis’te verdiği resmî sayıya göre, elli iki vatandaşımızın vefatına sebep olmuştur (Millet Meclisi Tutanak Dergisi, s.638). Henüz teşhisi kesinleşip kamuoyu ile paylaşılmamış olmakla birlikte, salgının başlangıcı ve basına yansıyan ilk haber bu olmuştur.

Ertesi günden itibaren ise basında konuyla ilgili haberler artmaya başlamıştır. Mevcut durum hakkında "salgın hastalık" ifadesini ilk kullanan gazetelerden olan Cumhuriyet Gazetesi'nin 14 Ekim 1970 tarihli haberine göre, hastalık sebebiyle bir kişi de hayatını kaybetmiştir (Bakar, 2017, s.248). 15 Ekim'de ise basına yansıyan hasta sayısı yüz elliden fazladır ve üç hasta da hayatını kaybetmiştir (Bakar, 2017, s.250). Bunlarla birlikte, henüz kolera değil, daha çok gıda zehirlenmesi ya da su aracılığıyla bulaşan bağırsak hastalığı olasılıkları üzerinde durulmaktadır. Haberlere göre, çeşitli uzmanlardan Sağlık ve Sosyal Yardım Bakanı Özkan'a verilen ilk bilgiler de bu yöndedir (Bakar, 2017, s.248). Bu nedenle, Sağlık ve Sosyal Yardım Bakanlığı tarafından resmî açıklama yapılmadan önce, salgının bir kolera salgını olduğu haberini ilk paylaşan, Cumhuriyet Gazetesi olmuştur. Gazetenin haberine göre, alınan ilk laboratuvar sonuçlarından gecekondu bölgelerinde sık bir şekilde görülen belirsiz hastalığın kolera olduğu anlaşılmaktadır. Ölü sayısı on dörde yükselirken, hastalığa yakalanarak hastanelere kaldırılanların sayısı da elliye yaklaşmış, bazı hastanelerde serum sıkıntısı baş göstermiştir. Çapa Mikrobiyoloji Enstitüsü yetkililerinin verdiği bilgiye göre, alınan ilk tahlil sonuçları hastalığın kolera olduğu şeklindedir. Ancak, bazı eksik bulgular mevcut olduğundan, daha kesin bir sonuç için numuneler Ankara'daki Refik Saydam (Hıfzıssıhha) Enstitüsü’ne gönderilmiştir. Yetkili profesörler, sonuç yüzde yüz kolera olmasa da, hastalığın koleraya çok benzeyen, aynı ölçüde bulaşıc1, tehlikeli ve benzer metodlarla tedavi edilecek bir hastalık olduğunu söylemişlerdir. Bu arada, Bakan Özkan da, ilaç firmalarının temsilcilerinden kolera tedavisinde kullanılan bazı antibiyotiklerin stok durumu hakkında bilgi almıştır (Cumhuriyet, 16 Ekim 1970).

Aynı habere göre, Sağlık ve Sosyal Yardım Bakanı Dr. Vedat Ali Özkan, Tıp Fakültelerinin dekanları ve mikrobiyoloji uzmanları ile bir toplantı düzenlemiş ve henüz kesin olarak kolera tespiti yapılmadığını, hastalığın kolerayı andıran bir şekilde seyrettiğini söylemiştir. Bakan, akşamüstü de ilaç firmalarının temsilcileriyle toplanmış ve "Tetrasiklin" grubu ${ }^{4}$ antibiyotik stokları hakkında bilgi aldıktan sonra, serum üreten Eczacıbaş1 Firması'ndan, hastalığın tedavisinde kullanılan serumun derhal üretilmesini istemiştir. Firma yetkililerinin verdiği bilgiye göre, diğer serumların üretimi askıya alınarak kolera tedavisinde kullanılan bu serumdan günde beş bin litre üretilecek, bu amaçla haftada yedi gün çalışılacaktır. Aynı yetkililer, ilk tertibi o gün tamamlanacak olan serumun, ishal ve kusma sebebiyle vücutta meydana gelen fazla tuz kaybını ve asiditeyi önleyici özellikte olduğunu belirtmişlerdir. Ancak, bir hastaya günde on-on beş litre serum gerektiğinden, hasta sayısı artarsa, ihtiyaç karşılanamayacaktır. Ayrıca, basında Sağmalcılar Cezaevi ile Bakırköy Ruh ve Sinir Hastalıkları Hastanesi'ndeki yüz elli boş yatağın kolera şüphesi olan hastalara tahsis edildiği, bölgedeki kuyuların klorlandığı, İstanbul dışındaki bazı sağlık ekiplerinin de İstanbul'a sevk edildiği ve salgın için yüz elli yataklı bir hastane hazırlandığı haberlerine de yer verilmiştir (Bakar, 2017, s.250).

Salgının bir kolera salgını olduğu ise kamuoyuna 17 Ekim günü açıklanmıştır. Basına yansıyan bilgilere göre, hastalıkla ilgili ilk kesin tahlil sonuçları Cerrahpaşa Tıp Fakültesi Mikrobiyoloji Servisi'nden alınmış ve "Para-Kolera" olarak tespit edilmiştir. Sonuç, yazılı

\footnotetext{
${ }^{4}$ Tetrasiklin, özellikle salgının devam ettiği yıllarda ciddi enfeksiyonların tedavisinde kullanılan bir antibiyotik grubudur.
} 
basın dışında TRT İstanbul Radyosu aracılığıyla da halka duyurulmuştur. Gazetelere yansıyan haberlerde ise mevcut ölüm ve hasta sayıları birbirinden oldukça farklıdır. Örneğin, Akşam Gazetesi, ölü sayısının ellinin, hasta sayısının ise binin üzerinde olduğunu iddia ederken (Akşam, 17 Ekim 1970), Tercüman Gazetesi'nde ölü sayısı yirmi yedi, hasta sayısı iki bin olarak açıklanmıştır (Tercüman, 17 Ekim 1970). Milliyet Gazetesi'nin resmî rakamlara dayandırdığı haberinde de ölü sayısı on dört, hastanede yatan hasta sayısıysa dört yüzdür. TRT ve Anadolu Ajansı ise "gayri resmî” ölü sayısını yirmi iki olarak açıklamıştır (Milliyet, 17 Ekim 1970).

Ayrıca, Para-Kolera, basında "koleranın hafif türü” olarak tarif edilmiştir. Uzmanlar, hastalığın hafif seyrettiğini ve Asya Kolerası kadar öldürücü olmadığını söylemektedir. Bununla birlikte, hastalığın Şişli'ye bağlı Esenler ve Küçükköy'de de görülmeye başladığı bilgisi verilerek 1912 yılında İstanbul' da on beş bin kişinin koleradan öldüğü hatırlatılmaktadır. Bu sebeple, hükümet, sıkılaştırdığı tedbirleri ve aldığı yasak kararlarını basınla da paylaşmıştır. Buna göre:

- Her çeşit kaplarla su satışı yasaklanmıştır. Kamyon ya da diğer araçlarla şehre içme suyu getirilmeyecektir.

- Dondurma dâhil tüm buzlu maddelerin satışı yasaklanmıştır. Hiçbir yiyeceğe buz eklenmeyecektir.

- Açıkta üretilip satılan lahmacun, köfte, balık, kokoreç, midye gibi ürünlerin satışı yasaklanmıştır.

- Okul, kahvehane, sinema, stadyum ve eğlence yerleri kantinlerinde yaş meyve ve sebze satışı yasaklanmıştır.

- Okullarda her çeşit meşrubatın satışı yasaklanmıştır.

- Hastalık görülen evlerde yaşayanlar beş gün dışarı çıkmayacak, bu evler dezenfekte edilecektir.

- Kolera hastalarını taşıyan araçlar her gün dezenfekte edilecek ve kesinlikle başka amaçla kullanılmayacaktır.

- Bütün tuvaletler kireç kaymağı ile dezenfekte edilecek, şehir suyu "süper klorlanacaktır".

- Enfekte olmuş suyla sulandığı tespit edilen bahçe ve bostanların tüm ürünleri derhal imha edilecektir.

- Cenazeler antiseptik bir maddeyle yıkanacak, mezarlara kireç suyu dökülerek defnedilecektir. Evde ölenlere de aynı yöntem uygulanacaktır (Milliyet, 17 Ekim 1970).

İstanbul'da başlayan salgın, aynı günlerde Batı basınının da dikkatini çekmeye başlamıştır. Örneğin, Amerika Birleşik Devletleri'nde yayımlanan New York Times Gazetesi, 17 Ekim 1970 tarihli sayısında İstanbul'daki salgına da yer vermiştir. Haberini, İstanbul'daki muhabirinin 16 Ekim'de gönderdiği bilgilere dayandıran gazete, Sağlık ve Sosyal Yardım Bakanlığı'nın Ankara'dan İstanbul'a bir milyon doz kolera aşısı getirttiği, İstanbul'daki hastanelerde salgın sebebiyle ölü sayısının yirmi yedi, hasta sayısının ise beş yüzden fazla olduğu, ilk ve orta dereceli okulların kapatılmasının düşünüldüğü ve Sağlık ve Sosyal Yardım Bakanı Özkan'ın çalışma arkadaşlarını İstanbul'da görüşmeye çağırdı̆̆ı bilgilerine yer vermiştir (New Yok Times, 17 Ekim 1970).

Ertesi gün salgın sebebiyle ölümlerin sayısındaki artış devam etmiştir. Basına yansıyan bazı haberlere göre 18 Ekim itibariyle ölenlerin sayısı kırk yediye yükselmiştir. Bunların arasında altı yaşında bir kız çocuğu da vardır. İstanbul'da Kadıköy, İstanbul dışında Kırıkkale, Çanakkale ve Samsun'da da Koleraya rastlanmıştır (Günaydın, 18 Ekim 1970). Çanakkale'nin Beşyol ilçesinde de kolera görüldüğü bildirilirken, Samsun'un Çarşamba ilçesinde belediye hoparlörlerinden bölgede kolera tespit edildiği bildirilmektedir. İki şehirdeki hastalar da İstanbul'dan gelmiştir (Hürriyet, 18 Ekim 1970). Yine basındaki haberlere göre, salgınla mücadele amacıyla ülke çapında dört bin doktor, İstanbul Tabipler Odası tarafından göreve davet edilmiştir. Hızlı müdahale amacıyla "yıldırım sağlık ekipleri”" kurulmuş ve vatandaşlara acil durum için kullanabilecekleri telefon numaraları duyurulmuştur. Bunlarla birlikte, yukarıda da ifade edildiği gibi, salgının merkezi olan Sağmalcılar'dan başka ilçe hatta illere kaçış amaçlı göçler başlamış ve bu göçler bulaşma riski ve hızını da artırmıştır. Bu sebeple, Kırklareli gibi bazı illerin İstanbul ile trafiği yasaklanmıştır (Akşam, 18 Ekim 1970). 
Ancak, hastalıktan ölenlerin cenazelerinin ailelerine teslim edilmemesi, bu salgından evde ölenlerin yakınlarının cenazelerini yetkililere vermemesine sebep olmuş, bu da salgının şiddetini artırmıştır. Ayrıca, salgından korunmak için meyve ve sebze satışı düşerken, limon ve sirkeye talep artmıştır. Turist gemileri de İstanbul'a seferlerini iptal etmiştir (Günaydın, 18 Ekim 1970).

Bununla birlikte, İstanbul'da aşılama amacıyla iki yüzden fazla merkez kurulmuş, İstanbul dışından sağlık ekipleri de destek amacıyla sevk edilmiştir. Vatandaşlar, aşı merkezlerinin önünde uzun kuyruklar oluşturmuştur (Günaydın, 18 Ekim 1970). İstanbul'da başlatılan yoğun bir aşı kampanyası ile salgının görüldüğü semtlerden başlanarak tüm İstanbul halkı zorunlu olarak aşılanmaya başlamış, bu sayı 18 Ekim itibariyle yüz bine ulaşmıştır (Tercüman, 18 Ekim 1970). Ayrıca, yazılı basında Sağlık ve Sosyal Yardım Bakanlığı açıklamasına dayandırılarak verilen ölü ve hasta sayıları bile farklılık göstermektedir. Örneğin, Vatan Gazetesi ölü sayısını yirmi beş, hasta sayısını ise beş yüz altmış olarak verirken (Vatan, 18 Ekim 1970), Her Gün Gazetesi'ne göre ölü sayısı yirmi yedi, hasta sayısı yedi yüz on yedidir (Her Gün, 18 Ekim 1970).

Sağlık ve Sosyal Yardım Bakanı Özkan, üç ay kadar sonra, Ocak 1971'de konuyla ilgili TBMM'de yaptığı açıklamada, aşı uygulaması için yalnız İstanbul'da bin merkez kurulduğunu, dört günde dört milyon vatandaşın aşılandığını ve dördüncü gün aşı kuyruklarının son bulduğunu söylemiştir (Millet Meclisi Tutanak Dergisi, s. 653).

Bakan, salgının sürdüğü 19 Ekim 1970 tarihinde mevcut durumla ilgili yaptığ1 açıklamada, salgının aslında iki buçuk aydır devam ettiğini, ancak "Íspanyol Nezlesi" şeklindeki yanlış teşhis sebebiyle yeni tespit edilebildiğini söylemiştir. Ayrıca, vatandaşların ücretsiz olarak aşılanmasının devam ettiğini, hükümet yaklaşık beş yıldır koleraya karşı tedbir almakta olduğundan, bir buçuk ay kadar önce dokuz milyondan fazla kişinin zaten aşılanmış olduğunu da eklemiştir. Yine Bakan'ın açıklamalarına göre, dün on dokuz kişi taburcu edilmiş, hastaların iyileşme hızı da artmıştır ve salgın kontrol altına alınmak üzeredir (Milliyet, 19 Ekim 1970).

Özkan, bunlarla birlikte, basında ölü ve hasta sayılarının gerçekte olduğundan çok yüksek şekilde yer almasından şikâyet etmiştir. Resmî sayılara göre, 19 Ekim itibariyle hastalık sebebiyle ölenlerin sayısı otuz, hasta sayısı ise dokuz yüz otuz altıdır. İstanbul'da da üç gün içinde iki milyon vatandaşa aşı uygulanmış ve aşı ücretsizdir. Uygulanan aşı, hastalığa karşı yüzde otuz-elli oranında ve dört ay süreyle koruma sağlamaktadır. Ankara' dan bir milyon doz daha aşı İstanbul'a getirilmiştir (Her Gün, 19 Ekim 1970). Hastalığın İstanbul dişındaki şehirlerde görüldügü haberlerini de yalanlayan ve hastanelerdeki durum hakkında da bilgi veren Bakan Özkan, yatak sıkıntısı olmadığını da ifade etmiştir. Örneğin, Yedikule Gögüs Hastalıkları Hastanesi'nde üç yüz doksan sekiz, Samatya İşçi Sigortaları Hastanesi'nde yüz doksan sekiz boş yatak bulunmaktadır (Babıali'de Sabah, 19 Ekim 1970).

Öte yandan, bu tarihlerde komşu ülkelerde de Türkiye'den ulaşabilecek muhtemel bir kolera salgınına karşı tedbirler alınmaya başlamıştır. Özellikle basında verilen abartılı haberlerden kaygı duyan Bulgaristan ve Yunanistan sınır kapılarını kapatmış, yolculara sıkı sağlık kontrolleri başlamıştır (Vatan, 19 Ekim 1970). Bulgaristan, Türkiye'den gelecek yolcuları kabul etmek için ilk aşının üzerinden beş gün geçmesi şartını uygularken, Yunanistan ise ikinci aşıyı talep etmiş ve ikinci aşının üzerinden beş gün geçmesini bekleme kararı almıştır (Akşam, 19 Ekim 1970).

\section{Salgının Hızının Düşmeye Başlaması ve Sona Ermesi}

20 Ekim 1970 günü dönemin İstanbul Valisi Vefa Poyraz’ın yaptığı açıklamaya göre, salgının hızı yüzde otuz üç oranında azalma gösterirken, aşı uygulanan vatandaş sayısı da iki 
milyon iki yüz bine ulaşmış, salgından dokuz kişi daha hayatını kaybetmiştir. (Akşam, 20 Ekim 1970) Ayrıca, kolera sebebiyle ölenlerin defin ruhsatlarına salgın sebebiyle vefat ettikleri eklenmiş, ilgililere mezara kireç dökülmesi gerektiği bilgisi verilmiş ve bu doğrultuda mezarlara on kg kireç dökülmesi istenmiştir. Herhangi bir sebeple mezarın en az üç yıl boyunca tekrar açılması da yasaklanmaktadır (Babıali'de Sabah, 20 Ekim 1970).

Vatandaşların tedbirlere yönelik hassasiyeti de artmaktadır. Okullarda da aşı kampanyası başlatılmış, kayıtlı tüm öğrencilere zorunlu aşı uygulanmasına karar verilmiştir. İki yüz kişi de iyileşerek taburcu olmuştur (Her Gün, 20 Ekim 1970). Salgının merkezi konumundaki İstanbul ile birlikte, başkent Ankara' da da tedbirler artmıştır. Numune Hastanesi ve Ulus Sosyal Sigortalar Hastanesi tümüyle olası kolera hastaları için ayrılmıştır. Buralarda bulunan mevcut hastalar ise Dışkapı Sosyal Sigortalar Hastanesi'ne gönderilmiştir. Ulus Sosyal Sigortalar Hastanesi Başhekimi Altan Ozantürk, hastanedeki yüz yatağın tümüyle kolera için ayrıldığını, bu tarihten itibaren en basit ishal şikâyetlerinin bile bu bölüme sevk edileceğini söylemiştir (Vatan, 20 Ekim 1970).

İstanbul Valisi Poyraz, 21 Ekim'de yeni bir açıklama yaparak, salgının seyri konusunda daha da iyimser olduğunu ifade etmiş, salgının hızındaki düşüşün yüzde altmışa ulaştığ1 bilgisini vermiş, hastalığın resmen açıklandığı 17 Ekim günü hastanelerde toplam iki yüz yirmi beş kolera hastası ya da şüpheli vaka bulunurken, 21 Ekim itibariyle kesin teşhisli hasta sayısının doksan sekize düştüğünü söylemiştir. Bununla birlikte, kesin sonuç alabilmek için salgınla mücadelenin beş yıl kadar daha sürdürülmesi gerektiğini vurgulamıştır (Akşam, 21 Ekim 1970). Sağlık ve Sosyal Yardım Bakanlığı Müsteşarlığı'nın açıklamasına göre ise kolera kaynaklı toplam ölüm sayısı kırk üçtür. İstanbul'da tüm vatandaşlar aşılanmış, bazı aşı uygulamalarının birden çok kez yapılması gerektiğinden, nüfus için gerekenden çok aşı tüketilmiştir. Olası yeni ihtiyaçlar dolayısıyla sekiz yüz kırk kg daha aşı getirtilmiştir (Her Gün, 21 Ekim 1970). Bakan Vedat Ali Özkan ise salgının bir "su epidemisi" olduğunu açıklamıştır (Hürriyet, 21 Ekim 1970). Sahada görev yapan doktorlar tarafından hazırlanan bilimsel çalışmalar da, Bakan'ın bu açıklamasını doğrulamakta ve salgının su aracılığıyla bulaştığını ifade etmektedir (Gürer ve Meriç, 1971, s.114). 22 Ekim'de ise yeni ölümlerin yaşanmaması, salgındaki gerilemenin iyice hızlandığını ve kontrol altına alındığını göstermiştir (Milliyet, 22 Ekim 1970). Sağmalcılar Belediyesi de, hastalığın hızını tümüyle kaybettiğini ve salgın eğrisinin başlangıç noktasına düştüğünü gösteren bir grafik hazırlayarak basına dağıtmıştır (Tercüman, 23 Ekim 1970).

Salgının hızını kaybetmesi ve ölüm sayısının iyice azalmasıyla birlikte, olayın ekonomik boyutu da araştırılmaya başlamıştır. Sınır kapılarının kapatılmış olması sebebiyle yaş meyve ve sebze ihracatı tamamen durmuş, eğlence mekânları gibi işletmeler de maddî açıdan zor durumda kalmıştır (Hürriyet, 24 Ekim 1970). Bu sebeple, Ticaret Bakanlığı, ihracat alanında tedbirler alındığını duyurmuş ve İtalya dışında hiçbir ülkenin henüz Türkiye'ye yönelik herhangi bir ticaret yasağı uygulamadığını açıklamıştır (Vatan, 25 Ekim 1970). Ancak, komşu ülkelerle sınırlar kapalı durumda olduğu gibi, salgın kendi ülkelerinde de görülmesine karşın pek çok Avrupa ülkesi de Türkiye'den yolcu kabul etmemektedir. Turizm ve Tanıtma Bakanı Necmettin Gevheri, salgının turizm sektörünü de olumsuz etkilediğini söylemiştir (Akşam, 31 Ekim 1970).

24 Ekim 1970 itibariyle resmî sayılara göre salgın sebebiyle gerçekleşen toplam ölüm sayısı kırk altı, hasta sayısı da bin yüz altmıştır. Hastanelerde bulunanların çoğu iyileşmiş, taburcu sürelerini beklemektedir (Tercüman, 24 Ekim 1970). Salgın Türkiye'de hızını kaybederken, komşu ülkelerde şiddetlenmeye ve Doğu Avrupa'da da görülmeye başlamıştır. Yunanistan, hasta sayısının artışı sebebiyle aşı uygulamasına başlamıştır (Babıali'de Sabah, 25 Ekim 1970). Çekoslovakya'da da üç kişinin Kolera sebebiyle öldüğü açıklanmıştır (Akşam, 28 Ekim 1970). Türkiye'de ise son günlerde yeni ölüm meydana gelmemiş, Bakan Özkan'ın Sağlık 
Şûrası'nda yaptığ açıklamaya göre, salgının hızı yüzde doksan oranında azalmıştır (Cumhuriyet, 28 Ekim 1970). Sınır kapıları da kısmen yeniden açılmış, Avrupa'ya araç çıkışları sınırlı olarak yeniden başlamıştır.

İstanbul'daki salgın hakkında haberlere zaman zaman sayfalarında yer veren New York Times Gazetesi, kolera sebebiyle gerçekleşen ölüm sayısının kırk dokuz olduğunu, salgının zirve noktasına geçen hafta ulaşıp inişe geçtiğini, hastanelerde bulunan hasta sayısı oranının tüm hasta sayısına göre \%10'a düştüğünü, tüm hastaların İstanbul'da bulunduğunu ve tespit edilmiş hasta sayısının bin iki yüz otuz beşe indiğini bildirmiştir. Bunlardan kesin kolera teşhisi konulanların sayısı ise dört yüz doksan dokuzdur. On kişinin de "sağlıklı taşıyıcı" olduğu tespit edilmiş ve karantina altına alınmıştır (New York Times, 28 Ekim 1970).

Fransa'da yayımlanmakta olan Le Monde Gazetesi de, New York Times'ın verdiği bilgileri doğrulamaktadır. Gazeteye göre, Türkiye'de hastalık sebebiyle son ölümler 25 Ekim'de gerçekleşmiş ve iki hasta hayatını kaybetmiştir. Haberin yayımlandığı gün gazeteye İstanbul muhabirinden gelen bilgiye göre, o gün boyunca seksen altı kişi kolera şüphesiyle hastaneye kaldırılırken, otuz kişi de taburcu edilerek evlerine gönderilmiştir. Salgın sebebiyle vefat eden kişi sayısı kırk dokuz, şüpheli hasta sayısı bin iki yüz otuz beştir. Türkiye'de koleraya karşı yaklaşık yirmi milyon kişi aşılanmış durumdadır. Fransa, İsviçre, Hollanda ve Almanya'dan da on iki milyon doz yeni aşı sipariş edilmiştir (Le Monde, 27 Ekim 1970).

Salgının hızını kaybetmeye başlamasıyla birlikte, hükümet, gelecekte yaşanabilecek benzer durumlar için yasal düzenleme yapma kararı almıştır. Bakan Özkan, bütün vatandaşların Sağlık Sigortası kapsamına alınması, üretimden tüketime kadar tüm gıda sektörünün sık1 denetimi ve bu denetimin yalnız Sağlık ve Sosyal Yardım Bakanlığı tarafından yapılması, tifo, para-tifo, dizanteri ve çocuk felci gibi hastalıkların azaltılması için kapsamlı bir çalışma başlatılması konularını içeren bir kanun tasarısı hazırladıklarını söylemiştir (Akşam, 29 Ekim 1970). Bakan Özkan, ayrıca, salgının hızının yüzde bire kadar gerilediğini ve tamamen kontrol altında olduğunu da açıklamıştır (Milliyet, 29 Ekim 1970). Öte yandan, salgına karşı tedbir almaya devam edilmiş, Ramazan ayının da başlaması sebebiyle camilerin de düzenli olarak dezenfekte edilmesine karar verilmiştir (Tercüman, 29 Ekim 1970). Ankara'da da aş1 uygulamasına yoğun şekilde devam edilmiş, şehirde bulunan tüm doktorlar, sağlık memurları, sağlık teknisyenleri, hemşire, hemşire yardımcıları ve hemşire okulları son sınıf öğrencilerinin görev aldığı aşı merkezlerinde dört günde yedi yüz elli bin kişi aşılanmıştır. Hafta sonuna kadar da tüm Ankaralıların aşılanması planlanmıştır (Vatan, 29 Ekim 1970).

Sağlık ve Sosyal Yardım Bakanlığı açıklamalarına göre, 1 Kasım 1970 tarihi itibariyle kolera kaynaklı yeni ölüm yoktur. Tespit edilen yeni hasta da olmamakla birlikte, mevcut hastaların sayısı hızla azalmakta ve taburcu işlemleri devam etmektedir. Tüm Türkiye çapında kolera teşhisi ya da şüphesiyle hastanelerde bulunan toplam hasta sayısı beş yüz yetmişe kadar düşmüş ve bunların da bir hafta içerisinde taburcu olmaları beklenmektedir (Vatan, 1 Kasım 1970; Zafer 1 Kasim 1970).

Bakan Özkan, 3 Kasım'da yaptığı açıklamayla 26 Ekim 1970 gününden beri kolera kaynaklı yeni bir ölüm gerçekleşmediği gibi herhangi yeni bir vakanın da kaydedilmediğini, dolayısıyla salgının artık tamamen kontrol altına alınarak sona erdiğini açıklamıştır. Bununla birlikte, tedbirlerin devam edeceğini ifade eden Özkan'ın verdiği rakamlara göre, 3 Kasım itibariyle Türkiye genelinde on beş milyon kişiye aşı uygulanmıştır. Aynı günlerde yapılan nüfus sayımına göre, Türkiye'nin toplam nüfusu yaklaşık otuz iki milyondur. Bununla birlikte, salgının yoğun olduğu bölgelerde yaşayan vatandaşlar, üç ay içinde ikinci kez aşılanacaktır. Stoklarda on beş milyon kişilik aşı stoku daha bulunmaktadır (Akşam, 3 Kasım 1970). 
Ayrıca, komşu ülkelerdeki salgın şiddetli olarak devam ettiğinden, sınırlardaki tedbirlerin artırılması için Hudut ve Sahiller Sağlık Genel Müdürlüğü’ne yaklaşık iki yüz bin liralık ek bütçe ayrılmıştır (Cumhuriyet Senatosu Tutanak Dergisi, s.1-3).

\section{Sonuc}

1961 yılında Filipinler'de başlayan "El Tor" tipi kolera salgını, 1965 yılı itibariyle Rusya ve İran'da etkili olmaya başlayarak sınırlarımıza dayanmıștır. Salgının komşu ülkelerde görülmesi üzerine, Türkiye'de tedbirler sıklaştırılmış, sınırlara kontrol birimleri ve laboratuvarlar kurulmuş, gümrük, hava ve deniz limanlarında denetimler başlamış, ilaç, serum ve tıbbî malzeme stoklanmış, yoğun bir aşı uygulaması başlatılmıştır. Alınan tedbirlerin de etkisiyle, salgının beş yıl kadar sınırlarımızın dışında tutulması başarılmış, ancak 1970 yılının sonlarında kolera ülkemize de ulaşmıştır. İlk tespiti İstanbul'un Sağmalcılar semtinde gerçekleșen salgın, su aracılığıyla bulaşarak ilk birkaç gün hızlı seyretmiş, tedbirlerin s1kılaștırılması ve yerinde müdahale sayesinde daha fazla büyümeden ve İstanbul sinırları içerisinde yaklaşık iki haftada kontrol altına alınmıştır. Bu süre içerisinde bin beş yüz kadar hastanın iyileşmesi sağlanmış, Bakanlık açıklamasına göre elli iki vatandaşımız da hayatını kaybetmiștir.

Tablo 1: Sağlık ve Sosyal Yardım Bakanlığı'nın doğrudan ya da basında yer alan açıklamalarına göre hasta ve vefat sayıları. (Çalışmada kullanılan kaynaklardan derlenmiştir.)

\begin{tabular}{l|l|l} 
Tarih & \multicolumn{1}{|c}{$\begin{array}{c}\text { Mevcut Kesin Teşhis ve Şüpheli } \\
\text { Hasta }\end{array}$} & Toplam Vefat \\
\hline 17 Ekim 1970 & 225 & Resmî bilgi yok \\
\hline 19 Ekim 1970 & 936 & 30 \\
\hline 20 Ekim 1970 & Resmî bilgi yok & 39 \\
\hline 21 Ekim 1970 & Resmî bilgi yok & 43 \\
\hline 24 Ekim 1970 & 1160 & 46 \\
\hline 25 Ekim 1970 & Resmî bilgi yok & 49 \\
\hline 27 Ekim 1970 & 1235 & 49 \\
\hline 1 Kasim 1970 & 570 & Resmî bilgi yok \\
\hline 8 Ocak 1971 (TBMM) & (İyileşen) +1500 & 52
\end{tabular}

\section{Kaynakça}

Bakar, C, (2017), "Kırk Yedi Yıl Sonra Yeniden Bir Salgının Hikâyesi: 1970 Sağmalcılar Kolera Salgınından Günümüze Dersler”, Turkish Journal of Public Health,15, (3), s.245-269

Cumhuriyet Senatosu Tutanak Dergisi (1971), Cilt 64, Toplantı 10, 18 Şubat 1971

Çalışkan, A, (2019), "XVIII. ve XIX.Yüzyılda Antep ve Civarında Bazı Salgın Hastalıklara Dair Bulgular”, Gaziantep University Journal of Social Sciences, 18, (4), s.1556-1573 
Çalışkan, A, (2020). "Osmanlı Kenti Bayezid'de Salgın Hastalıklar ve Bazı Asayiş Problemleri (XIX. Yüzyıl ve XX.Yüzyıl Başları)", Pamukkale Üniversitesi Sosyal Bilimler Enstitüsü Dergisi, 39, s. 1-19

Çalışkan, A ve Eyicil, A, (2019), "XVIII. ve XIX.Yüzyılda Halep ve Civarında Salgın Hastalıklar”, Bingöl Üniversitesi Sosyal Bilimler Enstitüsü Dergisi, 9, (18), Güz 2019, s.1289-1319

Gürer İ ve Meriç N, (1971), “2200 Kişilik Bir Toplumda Kolera Portörlüğü Araştırması”, Mikrobiyoloji Bülteni, 5, s.110-126

Kohn, G. C, (2008), Encyclopedia of Plagueand Pestilence: From Ancient Times to the Present (3.bask1.), New York: Facts On File, Inc.

Millet Meclisi Tutanak Dergisi (1971), Dönem 3, Cilt 9, 8 Ocak 1971Özlü Z, ve Çay M, (2020), Küresel Salgin ve Güvenlik: Tarihsel Süreç, Ed. Yunus Emre Tansü, Gaziantep: İKSAD, s. 15-48

Şehsuvaroğlu, B. N, (1958), Türkiye Karantina Tarihine Giriş, (İstanbul Üniversitesi Tıp Fakültesi Mecmuası, no:1, sene: 1958'den ayrı baskl), İstanbul: İstanbul Üniversitesi Tip Fakültesi

Yıldırım, N, (2010), İstanbul'un Sağlık Tarihi, İstanbul: İstanbul Üniversitesi

\section{Gazeteler}

Akşam, 17 Ekim 1970

Akşam, 17 Ekim 1970

Akşam, 18 Ekim 1970

Akşam, 19 Ekim 1970

Akşam, 20 Ekim 1970

Akşam, 21 Ekim 1970

Akşam, 28 Ekim 1970

Akşam, 29 Ekim 1970

Akşam, 31 Ekim 1970

Akşam, 3 Kasım 1970

Babıali'de Sabah, 19 Ekim 1970

Babiali'de Sabah, 20 Ekim 1970

Babıali'de Sabah, 25 Ekim 1970

Cumhuriyet, 16 Ekim 1970

Cumhuriyet, 28 Ekim 1970

Dünya, 19 Ağustos 1970

Günaydın, 18 Ekim 1970

Günaydın, 18 Ekim 1970

Günaydın, 18 Ekim 1970

Her Gün, 18 Ekim 1970 
Her Gün, 19 Ekim 1970

Her Gün, 20 Ekim 1970

Her Gün, 21 Ekim 1970

Hürriyet, 18 Ekim 1970

Hürriyet, 21 Ekim 1970

Hürriyet, 24 Ekim 1970

Milliyet, 18 Ağustos 1970

Milliyet, 17 Ekim 1970

Milliyet, 17 Ekim 1970

Milliyet, 19 Ekim 1970

Milliyet, 22 Ekim 1970

Milliyet, 29 Ekim 1970

Le Monde, 27 Ekim 1970

New Yok Times, 17 Ekim 1970

New Yok Times, 17 Ekim 1970

Tercüman, 17 Ekim 1970

Tercüman, 18 Ekim 1970

Tercüman, 23 Ekim 1970

Tercüman, 24 Ekim 1970

Tercüman, 29 Ekim 1970

Vatan, 18 Ekim 1970

Vatan, 19 Ekim 1970

Vatan, 20 Ekim 1970

Vatan, 25 Ekim 1970

Vatan, 29 Ekim 1970

Vatan, 1 Kasım 1970

Zafer, 1 Kasım 1970 